Relations industrielles

Industrial Relations

\title{
Barker, James R., The Discipline of Teamwork: Participation and Concertive Control
}

\section{Ann C. Frost}

Volume 55, numéro 1, 2000

URI : https://id.erudit.org/iderudit/051299ar

DOI : https://doi.org/10.7202/051299ar

Aller au sommaire du numéro

Éditeur(s)

Département des relations industrielles de l'Université Laval

ISSN

0034-379X (imprimé)

1703-8138 (numérique)

Découvrir la revue

Citer ce compte rendu

Frost, A. C. (2000). Compte rendu de [Barker, James R., The Discipline of Teamwork: Participation and Concertive Control]. Relations industrielles / Industrial Relations, 55(1), 179-180. https://doi.org/10.7202/051299ar

Tous droits réservés @ C Département des relations industrielles de l'Université Laval, 2000
Ce document est protégé par la loi sur le droit d'auteur. L'utilisation des services d'Érudit (y compris la reproduction) est assujettie à sa politique d'utilisation que vous pouvez consulter en ligne.

https://apropos.erudit.org/fr/usagers/politique-dutilisation/ 
basée sur les intérêts, et surtout à identifier les conditions et les stratégies pour en réussir l'implantation et le maintien.

MiChel GRANT

Département organisation et ressources humaines Université du Québec à Montréal

\section{The Discipline of Teamwork: Participation and Concertive Control}

by James R. BARKER, Thousand Oaks, Calif. : Sage Publications, 1999, 207 p., ISBN 0-7619-0369-0 (bond) and ISBN 0-7619-0370-4 (pbk).

James Barker's The Discipline of Teamwork makes a significant contribution to the already considerable literature on teams. In contrast to much of this literature, which focuses largely on how best to structure and implement teams for high performance, this work investigates teams as a mechanism for social control. Barker's book offers us a rare, critical look at the functioning of self managed teams, focusing in particular on how teams work to exert control over their members' behaviours. Barker recognizes explicitly that participation in such organizational forms has a price that workers are pressed to give more of their time and energy, to identify with the goals of the organization, and to collaborate effectively with their coworkers - all with obvious costs to their individual autonomy and personal lives.

The stated purpose of his book is threefold: to analyze how culture and control work in self-managed teams; to identify the consequences of a teambased culture; and to seek to change current thinking about these consequences so that teamwork can be made better for both the organization and for team members. The data upon which this study is based are drawn from the experiences of one firm: ISE Communications (a pseudonym), a manufacturer of electronic circuit boards used for voice and data transmission equipment. Barker gathered the data during three years of intensive field work in the early 1990s. During this time he was granted virtually unfettered access to management and workers at ISE, observing the manufacturing process, team meetings, more informal team interactions, and conducting hundreds of interviews with key informants.

Documenting the process by which the six self-managed teams at ISE came to develop their means of concertive control, Barker takes the reader inside teams to understand, in large part, why they are so successful - enabling management to do away with expensive supervision while ensuring the highly efficient production of high quality products. The heart of the book uses rich detail from Barker's conversations with informants and his observations from team interactions and meetings to document the process by which the teams adopted certain values; prioritized among competing values; converted their values into explicit, formalized rules; and then extracted compliance from members to those rules.

Barker shows through illustrative vignettes the power of the teams' control over their members. After early adoption of values that the teams believed would be functional for achieving the organization's objectives (such as good attendance, arriving to work and back from breaks on time, working for error free production, etc.), the teams quickly established specific and often writtendown guidelines or codes of conduct (such as, "if you come to work late three times and have made no effort to correct that problem, you will be let go"). These explicit rules were used to monitor and shape the behaviours of new team members who may not have had exposure to, and thus the opportunity to 
adopt, the original implicit value set. Because all team members knew the rules and had accepted their importance in shaping behaviours that produced the outcomes the team (and the organization) valued, team members were also expected to enforce the rules on one another. Thus, Barker documents two kinds of pressure on team members : not only to comply with the rules themselves, but also to ensure that the rules are complied with by the rest of the team's members.

The system Barker describes creates stress for those working in it. Team members describe for him the tension they feel working in this system with its accompanying, omnipresent pressure to follow the "rules" and to enforce them on others. Those who comply are rewarded by being made to feel an integral part of the team; while those who are perceived as failing to display the correct behaviours and attitudes are punished with guilt, peer pressure, and ultimately the loss of their job. Barker argues that the team system of value identification, adoption, and on-going monitoring creates a powerful system of supervision - much more controlling, he maintains, than the traditional supervisory hierarchy. Rather than Weber's iron cage, Barker points out that selfmanaged team members now live in a "lacy, steel-filigree cage" of their own making where, although team members feel more in control, they are certainly more controlled. Yet, much of this control takes place unbeknownst to workers. Concertive control, Barker states, is for team members, "a natural, seamless, and exceedingly subtle part of their lives" (note, p. 165).
The strength of Barker's work lies in the documenting of the process by which a team's system of concertive control is constructed. His insightful, indepth case evidence is compelling and the theoretical development he makes is a singular contribution of this work. Disappointingly, however, Barker fails to adequately address the negative consequences of the system he so carefully describes. Although explicitly setting out to understand the negative consequences of the system of concertive control so that it could be made better for both workers and the organization, Barker, in the end, sidesteps the issue. $\mathrm{He}$ in fact produces no evidence that the system leads to anything but ideal outcomes from the organization's perspective. Thus, he is confronted with the possibility that workers' can be made better off (he does document negative consequences for workers of the system) only by making the organization worse off. By working from a unitary perspective, in which he has assumed workers' and the organization's interests are aligned, Barker finds himself unable to address how the system can be made better for workers. Recognizing the potential for conflicting interests in the employment relationship would have enabled Barker to address the negative impacts of such a system on workers in a more substantive way and would have added considerably to the value of this book. Nonetheless, Barker's work makes a significant contribution to the field and students, unions, and industrial relations scholars would all gain valuable insights from this work.

ANN C. Frost

University of Western Ontario

\section{Les gouvernances de l'emploi : relations professionnelles et marché du travail en France et en Allemagne par Michel LALLEMENT, Paris : Desclée de Brouwer, 1999, 252 p., ISBN 2 - 220-04443-2.}

Comme l'indique le sous-titre, le plus récent ouvrage de Michel Lallement porte sur les relations professionnelles et le marché du travail en France et en 